\title{
АКТУАЛІЗАЦІЯ КАТЕГОРІЇ СПОСОБУ ДІЇ Й ФОРМУВАННЯ МОРФОЛОГІЧНОЇ ДОМІНАНТИ В РОСІЙСЬКОМОВНІЙ ПОЕЗІЇ НОВОГО ЧАСУ
}

у статті проаналізовано особливості поетичного функиіювання граматичних форм та значень дієслівної категорії способу дії в структурі російськомовних віршових текстів з морфологічною домінантою. Стверджується, що згущення форм наказового й умовного способу, що представлені маркованими членами триопозиційної системи способу дії дієслова, призводить до утворення дієслівної морфологічної домінанти з виділенням морфологічних форм, які створюють певне значення спонукання / бажаності або можливості виконання дії в теперішньому-майбутньому чи минулому за певних умов. Під час згущення дієстівних форм умовного способу їхня часова віднесеність є невизначеною поза межами контексту, що призводить до створення еффекту багатозначності й можливості полінттерпретації поетичного тексту. Згущення форм дійсного способу, що є немаркованими членами триопозиційної системи способу дії дієслова й мають менше виразне навантаження порівняно з формами наказового та умовного способів, формує фонову домінанту тіричного твору.

Ключові слова: поетичний текст, актуалізачія, згущення, морфологічна домінанта, граматична категорія, категорія способу діі дієслова.

Samsonenko N. I. Actualisation of the Category of Mood and Formation of Morphological Dominant in the Russian-Language Poetry of Modern Times. The article considers the features of the poetic functioning of grammatical forms and meanings of the verbal category of mood in the structure of Russian-language poetic texts with verbal morphological dominant of mood. The actuality of the research is determined by insufficient study of the phenomenon of the actualisation of morphological forms and meanings of the verbal category of mood leading to the formation of the poetic text morphological dominant of mood in modern linguistics. The purpose of the article is to analyse the texts with verbal morphological dominant of mood. The main tasks of the article are to identify regular ways of poetic actualisation of grammatical forms and meanings of the verbal category of mood, as well as to clarify their ability to form different types of verbal morphological dominant of the text. In the article it is proved that the condensation of the imperative and conditional mood forms, represented by marked members of the verbal three-position mood system, leads to the formation of morphological dominant of mood highlighting the selection of morphological forms that create a certain meaning of desirability, possibility of action performing in the present / future or in the past under certain 
conditions. It is asserted that in case of condensation of verbal forms of the conditional mood, their temporal relatedness is unspecified beyond the context, which creates the effect of poetic text polysemy and polyinterpretation. At the same time, condensation of forms of the indicative mood, that are unmarked members of the verbal threeposition mood system and have less expressiveness than the forms of imperative and conditional mood, can form the background dominant of the poetic text.

Key words: poetic text, actualisation, condensation, morphological dominant, grammatical category, verbal category of mood.

\section{Вступ}

Сучасні дослідження з лігвопоетики та лінгвістики тексту здійснюються в річищі пошуку граматичних особливостей віршового тексту та спрямовані на виокремлення значень, що містяться в тих чи тих граматичних формах, а також на визначення поетичних смислів, які вони передають.

Здебільшого увагу мовознавців привертають синтаксичні форми та структури, що пов’язані з різними засобами художньої виразності. Морфологічні ж одиниці, які також мають потужний експресивний поетичний потенціал, невиправдано відсуваються на другий план (порівняно з синтаксичними та лексичними). Усупереч наявності певних наукових здобутків з поетичної морфології (наприклад, роботи Я. Й. Гіна, О. К. Жолковського, Л. В. Зубової, І. О. Іонової, А. К. Мойсієнка, Н. А. Ніколіної, О. Г. Ревзіної, О. О. Скоробогатової, Л. П. Черкасової та інших дослідників), феномен підвищеної концентрації однотипних морфологічних одиниць у структурі віршового тексту, що призводить до утворення морфологічної домінанти та сприяє поетичному сенсотворенню, вивчений у сучасній лінгвопоетиці й лінгвістиці тексту фрагментарно.

Певні особливості художнього функціювання морфологічних форм категорій дієслова, наприклад часу й способу дії, висвітлювали дослідники художнього тексту (наприклад, роботи Ю. М. Лотмана, О. К. Жолковського, Л. В. Зубової, Н. А. Ніколіної, Л. Г. Панової). Відомо, що художня оповідь у ліричному творі може здійснюватися в плані реального чи ірреального наративу. Форми ірреальних дієслівних способів, до яких відносять деякі форми умовного, бажаного способів, $є$ достатньо дослідженими і в загальномовному ужитку, і у сфері поетичного вживання (Лотман, 1972). Художню оповідь у реальному плані (на противагу ірреальному) віршознавці відзначають рідко, i, 
отже, вона є вивченою фрагментарно, незважаючи на те, що кількість поетичних текстів з оповіддю в реальному плані значно превалює над текстами з оповіддю в ірреальному плані. Філологи відзначають, що «семантика наказового й умовного способів, яка безпосередньо пов'язана з комунікативними цілями висловлювання й намірами мовця, характеризується “сильною” інтенціональністю, тоді як дійсний спосіб виступає з цього погляду як немаркована форма» (тут і далі переклад наш - Н.С.) (Бондарко, 2002: 150). Реальний план оповіді, що представлений дієслівними формами дійсного способу в трьох часових площинах - теперішнього, минулого і майбутнього часів, у поетичному творі не є відміченим і виділеним. Увага дослідників на ньому зосереджується значно рідше, ніж на ірреальному плані оповіді, що у віршовому творі є відміченим, виділеним.

Актуальність теми нашого дослідження визначається загальною антропоцентричною спрямованістю філологічних досліджень і зумовлюється завданнями сучасної лінгвопоетики, що висуває на передній план питання вивчення експресивного потенціалу граматичних одиниць в умовах поетичного функціювання та дослідження способів формування поетичних смислів у віршовій мові на граматичному підгрунті.

Метою статті є дослідження особливостей поетичного функціювання граматичних форм і значень категорії способу дії дієслова в складі дієслівної морфологічної домінанти віршового тексту. Відповідно до мети поставлено такі завдання: 1) виокремити нерозв’язані проблеми теорії поетичного функціювання морфологічних категорій і форм, способу дії дієслова зокрема; 2) дослідити регулярні способи поетичної актуалізації граматичних форм і значень дієслівної категорії способу дії; 3) установити здатність останніх формувати різні типи дієслівних морфологічних домінант поетичного тексту, що є значущими для передачі певних поетичних смислів ліричного твору.

\section{Методи та методики дослідження}

Обрані методи дослідження зумовлені поставленою метою та окресленими завданнями. На всіх етапах роботи було застосовано загальнонаукові, лінгвістичні та інтерпретаційні методи. Описовий метод використано для загального аналізу, опису й систематизації 
поетичного ресурсу однотипних морфологічних одиниць у складі морфологічної домінанти поетичного тексту; функиійний метод спрямовано на вивчення поетичного потенціалу одиниць морфологічного рівня в їхньому художньому функціюванні; за допомогою методу інтерпретаційно-текстового аналізу схарактеризовано морфологічні способи реалізації авторського наміру щодо створення поетичного смислу.

\section{Результати та дискусії}

Тричленна структура категорій способу дії дієслова в російській мові представлена “немаркованим" членом системи - дійсним способом і «маркованими» членами - наказовим та умовним способами (Русская грамматика, 1979: 157). Основні функції форм наказового способу «сприймають у конкретизовано-звуженому сенсі, а саме в сенсі констатації ді ї <..>, яку - у момент говоріння - представляють як ре альн у (Русская грамматика, 1979: 186). Окрім того, «семантичній немаркованості відповідає н е в і д м і ч е н і с т ь у п л ан і в и ра жен н я (Русская грамматика, 1979: 185), тобто зафіксована відсутність спеціального формального компонента для вираження його значення. Дійсний спосіб як немаркований член граматичної опозиції характеризується розгалуженою системою формально-граматичних показників вираження його значення залежно від часу, особи, числа, роду (у минулому часі). У цьому разі немає спеціального формального компонента, який указує на те, що дію уявляють як реальну й об’єктивну. Дійсний спосіб як немаркований член граматичної категорії способу дії дієслова протиставляється наказовому та умовному способам як маркованим членам категорії, у яких набір формантів для вираження їхнього значення значно менший.

Стверджуємо, що актуалізована морфологічна форма категорії способу дії дієслова й / або створене співпозицією цих форм граматичне значення, що переважають в поетичному тексті і $€$ значущими для змістового вираження цього віршового твору, можуть утворювати дієслівну морфологічну домінанту способу дії. Основою формування морфологічної домінанти тексту вважаємо прийом морфологічної селекції (послідовного відбору морфологічних одиниць за певною ознакою), що є одним із трьох універсальних способів актуалізації нормативних граматичних форм і значень у мові поезії 
(Скоробогатова, 2012: 375-376). Одним з наслідків застосування морфологічної селекції є згущення на певному просторі поетичного тексту морфологічно подібних одиниць, що здатне перетворювати узагальнені граматичні значення останніх на більш часткові, ускладнюючи й конкретизуючи їхню семантику.

Наказовий спосіб, категоріальним значенням якого $€$ «значення спонукання, тобто подання дії як тієї, що вимагають, до якої спонукає когось мовець» (Русская грамматика, 1980 (Т. 1): 618), є маркованою граматичною категорією з певним набором формальних показників для вираження цього значення.

Розглянемо більш детально на прикладах. У вірші Юлії Олефір «Стал слишком грустным этот разговор...» (Олефир, 2013: 39) наказовий спосіб у формі 2-ї особи однини виконує роль звертання-прохання до спільної дії, що виражена часткою давай та формою “спільної дії” дієслова доконаного виду (Русская грамматика, 1980 (Т. 1): 620): Давай с тобой подпишем договор: / Тебе - свободу, мне - октябрь и Питер... Подальший граматичний рисунок вірша, у якому форми наказового способу є домінантними, показує певний поділ простору на “петербурзький” і “той, що залишився і знаходиться поза межами Петербурга”. Лексичний повтор дієслів брать, взять, забирать у формі наказового способу пов'язаний з чужим та далеким простором: Бери себе Москву и Амстердам, / Бери весь мир! Ну разве это мало?; Возьми себе Париж, Берлин и Прагу...; Возьми себе Нью-Йорка суету / И вечность Рима забирай, коль хочешь! Багаторазове повторення дієслова оставить у формі наказового способу пов'язане із простором Петербурга: Оставь мне этот город над Невой...; Оставь театры, храмы и мостыл...; Прошу: оставь хотя бь этот город!; Оставь на память о себе свет белой ночи...; Не забирай балтийскую мечту, / Оставь на память о себе свет белой ночи...; Прошу тебя: оставь хотя бы Питер. Звертання із проханням до ліричного адресата підкреслено внаслідок повторення дієслова просить у формі 1-ї особи однини. Наказовий спосіб у поетичному тексті передає «емоційну оцінку подій, що відбуваються, волевиявлення з боку мовця: схвалення - несхвалення, тяжіння - відштовхування, сприйняття - несприйняття, бажання продовжувати - зупинитись, згода - незгода, припущення - неприпущення» (Ковтунова, 1986: 121). У цьому поетичному творі наказовий спосіб актуалізує семантику антонімічної 
пари забирать - оставлять і відділяє простір Петербурга від усього іншого світу, підкреслюючи таким способом сприйняття автором міста на Неві як особливого простору, що пов'язаний зі спогадами про ліричного адресата; простору, що прийнятий автором, з одного боку, та іншого простору - простору «поза межами Пітера», далекого і чужого простору, з другого боку.

Домінанту цього поетичного твору становлять дієслівні форми наказового способу. Домінанта є дискретною, оскільки в цьому разі дієслівні форми дійсного способу (согреет, не отдам, не боюсь, знаю, уходишь, хочешь, забираешь) створюють певний граматичний план, на тлі якого дієслівні форми наказового способу виражають значення спонукання до дії. Формування дієслівної домінанти актуалізує значення спонукання до дії, що виражене за допомогою декількох форм - наказової форми дієслова 2-ї особи однини, а також частки давай з дієсловом спільної дії у формі майбутнього часу.

Переважання дієслівних форм наказового способу над формами дійсного способу спостерігаємо й у вірші Бахита Кенжеєва «...длись же, иночество, одиночество» (Кенжеев, 1995: 167). Імперативні форми зі значенням 2-ї особи однини длись, пролети, не плачь, пльви, угово$p u$, уведи, подари) й форми, утворені аналітичним способом за допомогою частки пусть (пусть окликает, пусть исчезнет) і 3-ї особи однини, визначають граматичний тон вірша, виводячи його в план спонукання до виконання бажаних дій. При цьому функції названих двох типів імперативних форм не однакові. В. В. Виноградов зауважує, що «у формі наказового способу у процесі вживання іiї не зі значенням 2-ї особи переважають модальні відтінки побажання, заклинання, припущення, того, що повинно бути. Отже, тут відбувається нібито перенесення форми наказового способу у сферу значень способу бажаності. 3 історичної позиції, можливо, було 6 більш правильним убачати в такому вживанні форми наказового способу відбитки його давніх значень, що пов'язані з його походженням з оптативу (способу бажаності)» (Виноградов, 1986: 481). Тобто імперативні форми зі значенням 2-ї особи однини та 3-ї особи однини мають різне значення в структурі дієслівної домінанти наказового способу в цьому вірші. Наказовий спосіб, що виражений формами 2-ї особи однини, звернений у поетичному тексті радше до душевного стану самотності ліричного героя, семантика чого актуалізована позицією звертання: 
... длись же, иночество, одиночество, / безответное, словно река... Наказовий спосіб у формі 3-ї особи однини з аналітичним елементом nусть звернений до країни походження і має значення бажаності щодо виконання дії: пусть отчизна по имени-отчеству / окликает меня, далека, / все, чем с детства владею, не властвуя, / nусть, приснившись, исчезнет скорей. Звертання до країни, де народився, на думку I. I. Ковтунової, є особливим типом звертання й відрізняється від інших не лише «характером своєї предметної віднесеності, але й різним ставленням до ситуації природного усного діалогу, форма якого переноситься в комунікативну ситуацію спілкування поета зі світом» (Ковтунова, 1986: 102). У цьому ліричному творі дискретна дієслівна домінанта наказового способу представлена двома різними формами, що виражають різну направленість висловлювання відносно адресата: звернення до себе, свого внутрішнього світу, що виражається формами 2-ї особи однини, і звертання, що спрямоване в зовнішній світ і має значення бажаності виконуваної дії, що й виражається часткою пусть у поєднанні з дієсловами 3-ї особи однини.

Попри домінування дієслівних форм наказового способу, у названих поетичних творах наявні форми дійсного способу, що становлять основу граматичної системи російського дієслова. Слід звернути увагу на співвідношення дієслівних форм наказового й дійсного способів у поданих віршах та інших поетичних творах з подібним «граматичним малюнком», тобто у творах з домінуванням дієслівних форм наказового способу на тлі представлених дієслівних форм дійсного способу. Форми наказового способу через свою меншу, порівняно з формами дійсного способу, частотність у нейтральному мовленні, а також через зв'язок з вольовою та емоційною сферами й звернення до реального чи уявного співрозмовника (унаслідок чого за цією ознакою їх відносять до маркованих членів граматичної категорії способу діiі) $є$ сильними виділеними формами. I. І. Ковтунова відносить наказовий спосіб до “сильних" ознак діалогічного мовлення поетичного тексту, тобто до тих, «що передбачають певну реакцію співрозмовника» (Ковтунова, 1986: 61). Зазначимо, що суцільна морфологічна домінанта способу дії в ліричному тексті виникає найчастіше за умови згущення немаркованих форм, а дискретна - за умови згущення маркованих форм (умовного й наказового способів). 
Наш матеріал свідчить, що в багатьох випадках дієслівні форми наказового способу дії виступають морфологічною основою поетичної молитви, яка є особливим жанром поезії та передбачає «звернення до вищих сил з метою спонукання їх до виконання волевиявлення адресата, а також з метою вираження почуттів вірянина. У поета зберігається ії невід’ємний компонент - прохання» (Морозова, 2015: 99). Відбувається вираження того самого значення за допомогою різних граматичних форм (форми наказового способу 2-ї особи однини, форми 3-ї особи множини / однини із часткою пусть, дай бог + інфінітив / іменник / підрядна частина зі сполучником чтобы), що становлять основу морфологічної домінанти твору. У випадку поетичної молитви морфологічна домінанта наказового способу дії, що передана різними граматичними формами, $є$ виразником того самого значення звернення із проханням (див. детальніше про це у роботі (Самсоненко, 2018: 61-64)).

Умовний спосіб у тричленній опозиції системи способу дії дієслова разом з формами наказового способу виконує роль маркованого члена опозиції й має «категоріальне значення можливості, припущення» (Русская грамматика, 1980 (Т. 1): 623). Дієслівні форми умовного способу виражають дію ірреальну, потенційно можливу або припустиму. Причому здебільшого «граматичним значенням форми умовного способу є значення можливості в невизначеному часовому плані» (Русская грамматика, 1980 (Т. 2): 102). Хоча така дія з ірреальним чи ірреально-умовним значенням може відноситися або до часового плану теперішнього-майбутнього як вираження побажання, потенційної можливості виконати дію зараз, у найближчому чи віддаленому майбутньому, або до часового плану минулого - як можливість виконання низки дій у минулому за певних умов. Морфологічна форма умовного способу дієслово минулого часу + частка «бы» не дає змоги розмежовувати за граматичною формою дії, що відносять до часового плану теперішнього-майбутнього або до часового плану минулого, як це можливо, наприклад, у європейських мовах інших груп. Зокрема, в англійській (If I knew, I would tell you. If I had known, I would have told you), французькій (Si je savais, je te dirais. Si j'avais su, je t'aurais dit), німецькій (Wenn ich das wissen würde, würde ich das dir sagen. Hätte ich das gewusst, hätte ich das dir gesagt). Російськомовні еквіваленти цих пар речень (Если бы я знал, я бы тебе сейчас сказал. 
Если бы я тогда знал, я бы тебе сказал) мають ідентичну граматичну форму, їх розрізняють або за допомогою семантики слів з часовим значенням, або контекстуально. Часто за відсутності слів із часовим значенням і контекстуальних маркерів у таких реченнях умовного типу часовий план «не може бути встановлений однозначно» (Русская грамматика, 1980 (Т. 2): 566). Наявність однієї морфологічної форми, що виражає віднесеність до того чи того часового плану, який не завжди чітко встановлюється, частково пов'язана з утратою граматичної форми плюсквамперфекта в російській мові, яка й виражала «минулу дію, що відбулася раніше за іншу минулу дію, а також віднесений до минулого результат дії, яка відбулася ще раніше» (Иванов, 1990: 327), що могло б дати змогу відносити часовий план умовного висловлювання до теперішнього / майбутнього чи минулого за граматичними показниками.

Тобто в російській мові речення з дієслівними формами умовного способу, зокрема й речення з дієслівними формами умовного способу, які функціюють «тільки як підрядна частина складного речення» (Русская грамматика, 1980 (Т. 2): 104), здебільшого мають невстановлений часовий план (теперішнього-майбутнього чи минулого). В окремих випадках актуалізації значення часового плану сприяють слова із часовим значенням і контекстуальне оточення. Тобто у конструкціях з дієслівною домінантою умовного способу можемо говорити про домінанту форми, у якій потенційно закладена віднесеність до певного часового плану, визначити який не завжди вдається. У тому разі, коли це можливо, актуалізації значення часового плану сприяють контекстуально-лексичні, проте не граматичні засоби.

Перейдемо до безпосереднього аналізу віршів з дієслівною домінантою умовного способу дії, що дозволить виявити деякі закономірності й особливості ії функціювання в поетичному тексті. Серед корпусу прикладів текстів з дієслівною домінантою умовного способу подано контексти, що їх відносять і до плану теперішнього-майбутнього (наприклад, Вероніки Доліної «Когда б»), і до плану минулого часу (наприклад, Олеся Ніколаєва «Иосиф»). Виявити співвіднесеність дієслівних форм умовного способу із часовим планом теперішнього-майбутнього чи минулого можливо тільки контекстуально: Когда б я сделалась стара, / Вокруг накрытого стола / Всю дюжину моих потомков / Однаждь б собрала (Долина, 2010: 340); ...когда б 
Иосиф, опороченный, / клеветами, уже в темнице, / на крюк в стене, на камень сточенныци, / на яд змеиный смог польститься, - // что было бы тогда? - инаково / судьба пошла бы? И юродом / смела б голодного Иакова / и Ханаан с его народом? (Книга, ради которой..., 2010: 176). У першому й у другому разі подано певну імпліцитну умову, за якої «нібито намічається перехід до вираження умовної та зумовленої дії» (Русская грамматика, 1979: 203). Умова, за якої відбудеться низка певних дій у теперішньому-майбутньому (когда б мы жили без затей...), або умова, за якої могла би відбутися низка дій (Когда б Иосиф <...> роптал и вопиял о мести).

Проте «потенційна багатозначність і поліреферентність слова в мові» (Скоробогатова, 2012: 24) у поетичному тексті багаторазово посилюється, що неминуче призводить до множинності інтерпретацій або до нерозрізнення певних значень. У поетичних творах із дієслівною домінантою умовного способу дії виявити віднесеність виражених висловлювань до плану теперішнього-майбутнього або минулого не є можливим. Наприклад, спостерігаємо подібну нейтралізацію у вірші Юлії Олефір «Я могла бы тебя не любить...» (Олефир, 2013: 85). Повторювана граматична структура дієслова з формою, що омонімічна формі минулого часу + частка «бы» + інфбінітив і відсутність точних часових показників розмивають темпоральні характеристики і виступають свідченням однієї з основних характеристик сучасного поетичного тексту - «поліінтепретованості», яка полягає в тому, що смисл поетичного твору не зводиться «до одного можливого змісту для усіх учасників спілкування» (Карасик, 2013: 194). Відбувається подібна позачасова віднесеність також унаслідок природного нерозрізнення в російській мові граматичних форм умовного способу, що відносить висловлювання до плану теперішнього-майбутнього або минулого.

У вірші Ольги Над’ярної «Отмена» (Надьярная) спостерігаємо суміщення декількох темпоральних шарів. Значення імпліцитної умови на початку першої строфи (если бы в жизни можно было нажать «отмену») й можливість наступних уявних подій ( звуком в моей вселенной, / я бы стала иветом в твоём монохромном мире / и мы вместе зажгли бы солние в пустой квартире) через відсутність обставин часу нейтралізовані. Дієслівні форми умовного способу передають подані дії як бажані й ті, що можливо здійснити в плані 
теперішнього-майбутнього або ті, що могли б бути здійснені в минулому. Імпліцитна умова на початку другої строфи (если бы только можно было нажать «назад») відносить наступні бажані дії до плану минулого, на що вказує лексема назад, тобто назад у минуле. Завершальна третя строфа не знімає окресленої багатозначності: только нас / никогда уже / не случилось. Це висловлювання, що побудоване з порушенням передбачуваності нас не случилось, сприймається як таке, що могло б відбутися, але не відбулося.

Форми умовного способу, що є маркованими формами триопозиційної системи способу дії дієслова, за умови згущення в межах одного текстового простору утворюють дієслівну домінанту умовного способу, яка на шкалі морфологічних засобів вираження експресивності поетичного тексту займає положення вищого порядку, на противагу нейтральним дієслівним формам дійсного способу, що представлений немаркованими членами граматичної опозиціі. Дієслівну домінанту умовного способу дії відносимо до типу морфологічної домінанти форми, під час використання якої одна й та сама граматична форма дієслово + минулий час + частка «бы» виражає значення ірреальної, потенційно можливої чи бажаної дії, при цьому значення часового плану вираженої дії може бути невизначеним або експлікованим часовими чи контекстуальними маркерами. Така властивість дієслівної домінанти умовного способу дії сприяє підвищенню ступеня багатозначності поетичного тексту.

Дієслова дійсного способу дії утворюють основу дієслівної системи російської мови. Дійсний спосіб, виступаючи немаркованим членом дієслівної категорії способу дії, загалом $є$ менш експресивним засобом граматичної виразності (але не виражальності - Н. С.), оскільки відображає реальну дію без співвіднесеності з планом бажаності чи ірреальності. Наприклад, вірш Сергія Потімкова «Я маюсь дурью, маюсь хмелем...» (Потимков, 2012: 31), у якому сформована суцільна домінанта дійсного способу з формами теперішнього, минулого та майбутнього часу, передає реальний план зображуваного за допомогою вживання дієслівних форм 1-ї особи теперішнього часу (зудит, идуm), майбутнього часу ((не) охранит) та минулого часу (был, спльл, зависла). У цьому разі дієслівна домінанта способу дії функціює разом з іншими засобами виразності, наприклад, зі співпозицією опозитивних часових форм, що формує поетичний 
смисл твору. Експресивність збільшує вживання сталих висловів (маюсь дурью; Был да сплыл; Сошел на нет), прийом контрасту (смысл безумныц̆; гений - идиот), метафори (Ижизнь компьютером зависла. / Зудит безумный Интернет; таскаю клавишу «delete»), алітерації (Идут подсиеты посещцений. / Подсчетам здесь такой почет!), використання вищого ступеня порівняння прислівника (Я все интимнее, все чаще).

\section{Висновки}

Згущення форм наказового й умовного способів, що представлені маркованими членами трипозиційної системи способу дії дієслова, призводить до утворення морфологічної домінанти способу дії 3 виділенням морфологічних форм, які створюють певне значення спонукання / бажаності або можливості виконання дії в теперішньому-майбутньому чи минулому за певних умов. Під час згущення морфологічних форм умовного способу їхня часова віднесеність $€$ невизначеною поза межами контексту, що призводить до створення ефекту багатозначності й поліінтерпретованості поетичного тексту. У багатьох випадках дієслівні форми наказового способу дії виступають морфологічною основою поетичної молитви, що передбачає «звернення до вищих сил з метою спонукання їх до виконання волевиявлення адресата, а також з метою вираження почуттів вірянина. Згущення дієслівних форм дійсного способу, що $є$ немаркованими членами триопозиційної системи способу дії дієслова й мають меншу експресивність порівняно з формами наказового та умовного способів, формує, за нашими спостереженнями, фонову домінанту ліричного тексту. Перспективами дослідження $є$ подальше всебічне вивчення різних типів морфологічної домінанти дієслова та імені, що функціюють у поетичному тексті.

\section{ЛIТЕРАТУРА}

1. Бондарко А. В. Теория значения в системе функциональной грамматики: На материале русского языка. Москва: Языки славянской культуры, 2002. 736 с. 2. Виноградов В. В. Русский язык. Грамматическое учение о слове: Учебное пособие. 3-е изд., испр. Москва: Высшая школа, 1986. 640 с. 3. Долина В. Фарфор. Москва: Эксмо, 2010. 352 с. 4. Иванов В. В. Историческая грамматика русского языка: учеб. для студентов пед. ин-тов по спец. «Рус. яз. и лит.». 3-е изд., перераб. и доп. Москва: Просвещение, 1990. 400 с. 5. Карасик В. И. Языковая матрица культуры. Москва: Гнозис, 2013. 320 с. 6. Кенжеев Б. Стихотворения. Москва: АО Издательство «ПАN», 1995. 256 с. 7. Книга, 
ради которой объединились поэты, объединить которых невозможно. Москва: РИПОЛ классик, 2010. 272 с. 8. Ковтунова И. И. Поэтический синтаксис. Москва: Наука, 1986. 206 с. 9. Лотман Ю. М. Анализ поэтического текста. Структура стиха. Ленинград: Просвещение, 1972. 271 с. 10. Морозова М. А. Стихотворная молитва в творчестве С. С. Бехтеева (на материале стихотворения «Пошли нам, Господи, терпенье...»). Пушкинские чтения. 2015. № XX. С. 96-101. 11. Надьярная О. «Отмена» URL: https:// www.stihi.ru/2016/08/16/8411 (дата звернення: 15.09.2016). 12. Олефир Ю. Я - кошка. Стихи. Донецк: Изд-во «Світ книги», 2013. 164 с. 13. Потимков С. Ю. «Тошіba» / худож.-оформитель О. Н. Артёменко. Харьков: Фолио, 2012. 191 с. 14. Русская грамматика / ред. кол. В. Барнетова, Е. Беличова-Кржижкова, О. Лешка, 3. Скоумалова, В. Стракова; науч. ред. К. Горалек. Прага: ACADEMIA PRAHA, 1979. T. 1. 664 c. 15. Русская грамматика. В 2-х т. / ред. кол. Н. Ю. Шведова и др. Москва: Наука, 1980. Т. 1. Фонетика. Фонология. Ударение. Интонация. Словообразование. Морфология. 784 с. 16. Русская грамматика. В 2-х т. / ред. кол. Н. Ю. Шведова и др. Москва: Наука, 1980. T. 2. Синтаксис. 709 с. 17. Самсоненко Н. I. Морфологічна домінанта наказового способу дії дієслова і жанр поетичної молитви (на матеріалі російськомовної поезії XIXXXI століть) International scientific and practical conference "Phililogy in EU countries and Ukraine at the modern stage": Conference proceedings (Baia Mare, 21-22 December 2018). Baia Mare: Izdevnieciba "Baltija Publishing", 2018. С. 61-64. 18. Скоробогатова Е. А. Грамматические значения и поэтические смыслы: поэтический потенциал русской грамматики (морфологические категории и лексико-грамматические разряды имени): моногр. Харьков: НТМТ, 2012. 480 с.

\section{REFERENCES}

1. Bondarko, A. V. (2002). Teoriya Znacheniya v Sisteme Funktsional'noy Grammatiki: na Materiale Russkogo Yazyka [The Theory of Meaning in the System of Functional Grammar: On the material of the Russian language]. Moskva: Yazyki slavyanskoy kul'tury [in Russian]. 2. Vinogradov, V. V. (1986). Russkiy Yazyk. Grammaticheskoye Ucheniye o Slove: Uchebnoye Posobiye [The Russian Language. Grammatical Study of the Word: Textbook]. Moskva: Vysshaya shkola [in Russian]. 3. Dolina, V. (2010). Farfor [Porcelain]. Moskva: Eksmo [in Russian]. 4. Ivanov, V. V. (1990). Istoricheskaya Grammatika Russkogo Yazyka: Ucheb. dlya Studentov Ped. In-tov po Spets. "Rus. yaz. i lit.» [Historical Grammar of the Russian Language: Textbook for Students of Ped. Inst. in Spec."The Rus. Lang. and litr.»]. Moskva: Prosveshcheniye [in Russian]. 5. Karasik, V. I. (2013). Yazykovaya Matritsa Kul'tury [Languistic Matrix of Culture]. Moskva: Gnozis [in Russian]. 6. Kenzheyev, B. (1995). Stikhotvoreniya [Poems]. Moskva: AO Izdatel'stvo «PAN». [in Russian]. 7. Kniga, Radi Kotoroy Ob»yedinilis' Poety, Ob»yedinit' Kotorykh Nevozmozhno [A Book for the Sake of which Poets, who cannot be united, have united]. (2010). Moskva: RIPOL klassik, 2010 [in Russian]. 8. Kovtunova, I. I. (1986). Poeticheskiy Sintaksis [Poetical Syntax]. Moskva: Nauka [in Russian]. 9. Lotman, Yu. M. (1972). Analiz Poeticheskogo Teksta. Struktura Stikha [Analysis of the Poetic Text. The Structure of the Poem]. Leningrad: Prosveshcheniye [in Russian]. 10. Morozova, M. A. (2015). Stikhotvornaya Molitva v Tvorchestve S. S. Bekhteyeva (na Materiale Stikhotvoreniya «Poshli nam, Gospodi, Terpen'ye...») [Poetic Prayer in the Works of S. S. Bekhteev (a Case Study of the Poem «Send us, Lord, Patience ...»)]. Pushkinskiye chteniya - Pushkin Readings, XX, 96-101 [in Russian]. 11. Nad'yarnaya, O. "Otmena» 
[“Cancellation"]. Retrieved from https://www.stihi.ru/2016/08/16/8411 [in Pussian]. 12. Olefir, Yu. (2013). Ya - Koshka. Stikhi [I am a Cat. Poems]. Donetsk: Izdatel’stvo «Svít knigi» [in Russian]. 13. Potimkov, S. Yu. (2012). «Toshiba» [«Toshiba»]. Khar'kov: Folio [in Russian]. 14. Barnetova, V. \& Belickova-Krizkova, H. \& Leska, O \& Skoumalova, Z. \& Strakova. V. (Ed.). (1979). Russkaya Grammatika [Russian Grammar]. (Vol.1). Praha: ACADEMIA PRAHA [in Russisan]. 15. Shvedova, N. Y. and others (Ed.). (1980). Russkaya Grammatika [Russian Grammar]. (Vol.1). Fonetika. Fonologiya. Udareniye. Intonatsiya. Slovoobrazovaniye. Morfologiya [Phonetics. Phonology. Stress. Intonation. Word formation. Morphology]. Moskva: Nauka. [in Russian]. 16. Shvedova, N. Y. and others (Ed.). (1980). Russkaya Grammatika [Russian Grammar]. (Vol.2). Sintaksis [Syntax]. Moskva: Nauka [in Russian]. 17. Samsonenko, N. I. (2018). Morfolohichna Dominanta Nakazovoho Sposobu Diyi Diyeslova i Zhanr Poetychnoyi Molytvy (na Materiali Rosiys'komovnoyi Poeziyi XIXXXI stolit') [Morphological Dominant of the Imperative Mood of the Verb and the Genre of Poetic Pray (a Case Study of the Russian-language Poetry of the XIX-XXI centuries)]. International scientific and practical conference "Phililogy in EU countries and Ukraine at the modern stage": Conference proceedings. (pp. 61-64). Baia Mare: Izdevnieciba "Baltija Publishing" [in Ukrainian]. 18. Skorobogatova, Y. A. (2012). Grammaticheskiye Znacheniya i Poeticheskiye Smysly: Poeticheskiy Potentsial Russkoy Grammatiki (Morfologicheskiye Kategorii i Leksiko-Grammaticheskiye Razryady Imeni) [Grammatical Meanings and Poetical Senses: Poetical Potential of Russian Grammar (Morphological Categories and LexicoGrammatical Classes of Noun)]. Kharkov: NTMT [in Russian].

Самсоненко Наталія Ігорівна - кандидат філологічних наук, доцент кафедри педагогіки, іноземної філології та перекладу, Харківський національний економічний університет ім. С. Кузнеця. Пр-т Науки, 9-А, м. Харків, 61166, Україна.

Tel: +38-068-277-34-47

E-mail: samsonenko.nataliia@gmail.com

ORCID: orcid.org/0000-0002-3319-5989

Samsonenko Nataliia Ihorivna - Ph.D. in Philology, Associate Professor, Department of Pedagogy, Foreign Philology and Translation, Semen Kuznets Kharkiv National University of Economics. Nauky Ave, 9-A, Kharkiv, 61166, Ukraine.

Надійшла до редакції 16 жовтня 2019 року 